\title{
Transformation in Micrococcus radiodurans: Measurement of Various Parameters and Evidence for Multiple, Independently Segregating Genomes per Cell
}

\author{
By SIMIN TIRGARI† AND B. E. B. MOSELEY* \\ Department of Microbiology, University of Edinburgh, School of Agriculture, \\ Edinburgh EH9 $3 J G$
}

(Received 6 February 1980)

\begin{abstract}
Transformation frequencies greater than $1 \%$ for some single markers were obtained in Micrococcus radiodurans when bacteria in the exponential phase of growth were resuspended in fresh growth medium containing $0.03 \mathrm{M}^{-\mathrm{Ca}^{2+}}$ before being incubated with transforming DNA. $\mathrm{Mg}^{2+}, \mathrm{Sr}^{2+}$ or $\mathrm{Zn}^{2+}$ could not replace $\mathrm{Ca}^{2+}$ in giving high frequencies of transformation. The time required for the maximum expression of transformed markers was 2 to $3 \mathrm{~h}$ for resistance to rifampicin and acriflavin and 6 to $8 \mathrm{~h}$ for resistance to erythromycin, kanamycin and streptomycin. The comparative frequency of transformants at maximum expression for each resistance marker was: kanamycin, 1; streptomycin, 1; acriflavin, 4; erythromycin, 25; rifampicin, 64.

Cultures were competent during all stages of exponential growth, the frequency of transformants only falling during stationary phase. The minimum time for DNA to be taken up by $M$. radiodurans into a DNAase-resistant form was between 3 and $6 \mathrm{~s}$. From $6 \mathrm{~s}$ to $10 \mathrm{~min}$ exposure to DNA, the number of transformants increased non-linearly with time as though the process was inducible. The transformation frequency was directly proportional to the DNA concentration up to $1 \mu \mathrm{g} \mathrm{ml}^{-1}$, although even at $88 \mu \mathrm{g} \mathrm{ml}^{-1}$ the bacteria were not saturated. Attempts to measure the fraction of cells which were competent, using the unlinked marker technique, gave values well in excess of one. These were interpreted in terms of multiple genome copies and approximate values of between 0.25 and 0.72 were derived for the competent fractions.
\end{abstract}

\section{INTRODUCTION}

Micrococcus radiodurans is characterized by its extreme resistance to the lethal effects of ionizing and ultraviolet radiations (Anderson et al., 1956; Duggan et al., 1959) and to chemical damage to its DNA (Moseley, 1967; Sweet \& Moseley, 1976). It is also resistant to mutation induced by these treatments, although it is sensitive to the mutagenic action of $N$-methyl- $N^{\prime}$-nitro- $N$-nitrosoguanidine (Sweet \& Moseley, 1974; Kerszman, 1975). Transformation was first demonstrated in M. radiodurans by Moseley \& Setlow (1968) and it remains the only method by which DNA repair and mutation in this organism can be studied genetically. However, the transformation frequencies reported to date have been low, and although transformation has been used to investigate the repair of irradiated transforming DNA (Moseley \& Setlow, 1968), the assignment of mutations affecting DNA synthesis and repair to various genes (Moseley et al., 1972b; Moseley \& Copland, 1978) and as an indicator of recombinational activity (Moseley et al., 1972a; Moseley \& Copland,

$\dagger$ Present address: Department of Biology, University of Teacher Training, 49 Roosvelt Avenue, Tehran, Iran. 
1975), very little effort has been made to increase the transformation frequency to those levels found in other systems, e.g. Diplococcus pneumoniae (Hotchkiss, 1954) and Haemophilus influenzae (Spencer \& Herriot, 1965). An improved transformation frequency would be of great benefit since in a bacterium where transformation is the only means of genetic exchange the possibilities for strain construction would be considerably enhanced. Thus, a non-selectable mutation could be transformed into a recipient with an excellent chance of the transformant being detected by replica-plating, e.g. a $\mathrm{Rec}^{-}$mutation into a recipient defective in some other repair pathway.

This paper describes a procedure which gives high transformation frequencies and some of the properties of the $M$. radiodurans transformation system.

\section{METHODS}

Bacteria. Organisms used were a wild-type Micrococcus radiodurans, originally isolated by Anderson et al. (1956), sensitive on TGY agar to $5 \mu \mathrm{g}$ kanamycin $\mathrm{ml}^{-1}, 4 \mu \mathrm{g}$ rifampicin $\mathrm{ml}^{-1}, 1 \mu \mathrm{g}$ acriflavin $\mathrm{ml}^{-1}, 2 \mu \mathrm{g}$ streptomycin $\mathrm{ml}^{-1}$ and $2 \mu \mathrm{g}$ erythromycin $\mathrm{ml}^{-1}$, and a multiple mutant of $M$. radiodurans (Krase), resistant

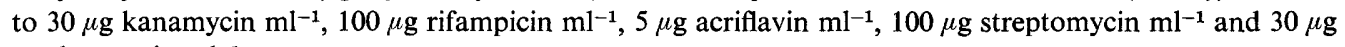
erythromycin $\mathrm{ml}^{-1}$.

Media. TGY medium for growth contained $5 \mathrm{~g}$ Bactotryptone (Difco), $1 \mathrm{~g}$ glucose and $3 \mathrm{~g}$ yeast extract (Difco) in 11 distilled water. TGY agar was made by solidifying this medium with $15 \mathrm{~g} \mathrm{Bactoagar} \mathrm{l}^{-1}$. TY medium was as TGY medium but without glucose. Phosphate buffer $(0.067 \mathrm{M}, \mathrm{pH} 7.0)$ contained $4.73 \mathrm{~g}$ $\mathrm{Na}_{2} \mathrm{HPO}_{4}$ and $4.54 \mathrm{~g} \mathrm{KH}_{2} \mathrm{PO}_{4}$ in 11 distilled water.

Chemicals. All inorganic chemicals and the amino acids (tryptophan, arginine, alanine, tyrosine and glutamic acid) were from B.D.H.

Growth of bacteria. Samples from $18 \mathrm{~h}$ cultures were diluted into $20 \mathrm{ml}$ quantities of TGY medium and the cultures were swirled in $250 \mathrm{ml}$ conical flasks at $30^{\circ} \mathrm{C}$. Turbidity readings were made in a nephelometer (EEL, Halstead, Essex) with an orange filter. A turbidity of 0.30 was equivalent to $1.0 \times 10^{8}$ viable units $\mathrm{ml}^{-1}$.

Preparation of transforming $D N A$. Two 11 cultures of the antibiotic-resistant strain of $M$. radiodurans were incubated at $30{ }^{\circ} \mathrm{C}$ with shaking until they reached the stationary phase. The cultures were centrifuged, the bacteria washed in $50 \mathrm{ml} \mathrm{SSC}$ buffer $(0.15 \mathrm{M}-\mathrm{NaCl} / 0.015 \mathrm{M}$-sodium citrate; $\mathrm{pH} 7.0)$ resuspended in $50 \mathrm{ml}$ butanol-saturated phosphate buffer $\mathrm{pH} 7 \cdot 0$ and left at room temperature for $45 \mathrm{~min}$. The suspension was centrifuged, the bacteria were resuspended in $50 \mathrm{ml}$ tenfold-diluted SSC buffer, lysozyme (EC 3.2.1.17, Sigma) was added to a final concentration of $20 \mathrm{mg} \mathrm{ml}^{-1}$ and the mixture was incubated at $37^{\circ} \mathrm{C}$ until a small sample $(0 \cdot 1 \mathrm{ml})$ removed to a test tube was completely lysed when one drop of $20 \%(\mathrm{w} / \mathrm{v})$ sodium dodecyl sulphate (SDS) in water was added (10 to $20 \mathrm{~min}$ ). Then $5 \mathrm{ml} \mathrm{20 \%}$ SDS was added to lyse the whole bacterial suspension. The subsequent procedure followed that described by Marmur (1961). The DNA was finally dissolved in SSC buffer at a concentration of 0.6 to $2 \mathrm{mg} \mathrm{ml}^{-1}$. The DNA concentration was calculated by its absorbance at $260 \mathrm{~nm}$.

Procedure for transformation experiments. To $0.05 \mathrm{ml}$ quantities of DNA (at various concentrations depending on the experiment) in test tubes held in ice $0.3 \mathrm{ml}$ amounts of bacterial culture (treated in various ways as required) were added and the tubes were incubated with gentle shaking at $30^{\circ} \mathrm{C}$ in a water bath. At the end of this period (usually $90 \mathrm{~min}$ ), DNAase (EC 3.1.21.1;0.05 ml;2.5 mg ml-1 ; Sigma) was added and incubation was continued for a further $15 \mathrm{~min}$. The contents of each tute were then diluted appropriately in TGY medium, $1 \mathrm{ml}$ samples were placed in sterile Petri dishes and $9 \mathrm{ml}$ amounts of molten TGY agar at $46{ }^{\circ} \mathrm{C}$ were added to each. The plates were swirled several times to ensure even distribution of the bacteria, the agar was then allowed to solidify and the plates were incubated at $30^{\circ} \mathrm{C}$. After varying periods of time, determined experimentally, a second $10 \mathrm{ml}$ layer of molten TGY agar was added containing the appropriate antibiotic ( $40 \mu \mathrm{g}$ kanamycin $\mathrm{ml}^{-1}, 4 \mu \mathrm{g}$ rifampicin $\mathrm{ml}^{-1}, 2 \mu \mathrm{g}$ acriflavin $\mathrm{ml}^{-1}, 2 \mu \mathrm{g}$ streptomycin $\mathrm{ml}^{-1}$ or $10 \mu \mathrm{g}$ erythromycin $\mathrm{ml}^{-1}$ ), allowed to solidify and the plates were incubated at $30^{\circ} \mathrm{C}$ for $4 \mathrm{~d}$ before transformant colonies were counted. Control plates from tubes lacking DNA were included in each experiment to measure the spontaneous mutation frequencies and the DNA was also checked for sterility.

Time required for maximum expression of transformed markers. Cultures prepared for transformation were added to transforming DNA in the ratio $0.3 \mathrm{ml}$ culture to $0.05 \mathrm{ml}$ DNA $\left(1.5 \mathrm{mg} \mathrm{ml}^{-1}\right)$ and incubated for $90 \mathrm{~min}$ before DNAase $(0.05 \mathrm{ml})$ was added for a further $15 \mathrm{~min}$. The cultures were diluted appropriately, $1 \mathrm{ml}$ samples were distributed into sterile Petri dishes and $9 \mathrm{ml}$ amounts of molten TGY agar were added. When set, the plates were incubated at $30^{\circ} \mathrm{C}$. Agar overlays $(10 \mathrm{ml})$ containing the antibiotics or acriflavin were added after various times of incubation, from 0 to $6 \mathrm{~h}$, and the number of transformants resistant to each inhibitor was assayed. 
Transformation frequency as a function of culture turbidity. Cultures of $M$. radiodurans were set up so that they were in exponential phase growth at a turbidity of $0.15\left(5 \times 10^{7}\right.$ viable units $\left.\mathrm{ml}^{-1}\right)$ after overnight incubation. As the culture turbidity increased samples of decreasing size were removed so that when centrifuged and resuspended in a standard volume of fresh TGY medium containing $\mathrm{Ca}^{2+}$ approximately the same bacterial concentration was obtained. Samples of $0.3 \mathrm{ml}$ were incubated with $0.05 \mathrm{ml}$ transforming DNA $\left(1.5 \mathrm{mg} \mathrm{ml}^{-1}\right)$ in SSC buffer for $90 \mathrm{~min}$, then DNAase was added for $15 \mathrm{~min}$ and the culture was assayed for transformants resistant to rifampicin.

DNA saturation curve. DNA $\left(620 \mu \mathrm{g} \mathrm{ml}^{-1}\right)$ in SSC buffer was serially diluted in SSC buffer and $0.05 \mathrm{ml}$ of each dilution was added to test tubes at $30^{\circ} \mathrm{C}$. A $0.3 \mathrm{ml}$ sample of culture of $M$. radiodurans prepared for transformation was added to each tube and incubation was continued for $90 \mathrm{~min}$ before $0.05 \mathrm{ml}$ DNAase $\left(2.5 \mathrm{mg} \mathrm{ml}^{-1}\right)$ was added to each tube for $15 \mathrm{~min}$. The cultures were diluted appropriately, $1 \mathrm{ml}$ samples were plated in agar and a rifampicin agar overlay was added after a further $4 \mathrm{~h}$ expression time.

Kinetics of $D N A$ uptake. An exponential phase culture of $M$. radiodurans was prepared for transformation. Samples $(0.3 \mathrm{ml})$ were added to $0.05 \mathrm{ml}$ amounts of transforming DNA (see Fig. 4 legend for concentrations) in test tubes and incubated at $30^{\circ} \mathrm{C}$. At increasing times, from $3 \mathrm{~s}$ to $90 \mathrm{~min}, 0.05 \mathrm{ml}$ DNAase $\left(2.5 \mathrm{mg} \mathrm{ml}^{-1}\right)$ was added to a different tube and incubation was continued for a total of $105 \mathrm{~min}$. As a control on the effectiveness of the DNAase, $0.3 \mathrm{ml}$ culture was added to $0.05 \mathrm{ml}$ DNAase, then $0.05 \mathrm{ml}$ DNA was added immediately and the mixture was incubated for $105 \mathrm{~min}$. Each tube was assayed for the number of transformants resistant to rifampicin or, in one experiment, acriflavin.

The unlinked marker technique for assaying competence. Transforming DNA prepared from the Krase strain of $M$. radiodurans was used to transform populations of the wild-type, prepared for transformation as described. The inhibiting agar overlay to select transformants was added at an appropriate time to give maximum expression of the transformed marker $(4 \mathrm{~h}$ for rifampicin and acriflavin, 6 to $8 \mathrm{~h}$ for streptomycin and erythromycin). When two inhibitors were added together to select double transformants, the overlay was added at a time to give maximum expression to both markers.

\section{RESULTS}

\section{Effects of divalent cations on the frequency of transformation}

Various treatments were compared for their effect on the frequency of transformation. Cultures were grown in TGY or TY medium and transformed with no further treatment or the bacteria were resuspended in fresh TGY or TY medium or they were resuspended in TGY or TY medium with $\mathrm{CaCl}_{2}$ added to a final concentration of $0.03 \mathrm{M}$, before being transformed (Table 1). The only treatment which caused a large increase in the frequency of transformation was the addition of $\mathrm{CaCl}_{2}$. The presence or absence of glucose in the growth or transformation medium had no effect. The presence, singly, of the amino acids tryptophan, arginine, alanine, tyrosine and glutamic acid at a concentration of $100 \mu \mathrm{g} \mathrm{ml}^{-1}$ did not increase the transformation frequency (results not shown).

Table 1. Comparison of various treatments to cultures of $M$. radiodurans on the transformation frequencies of two markers, rifampicin- and erythromycin-resistance

\begin{tabular}{|c|c|c|c|c|c|}
\hline $\begin{array}{l}\text { Growth } \\
\text { medium }\end{array}$ & $\begin{array}{l}\text { Resuspending } \\
\text { medium }\end{array}$ & $\begin{array}{l}\mathrm{Ca}^{2+} \\
\text { added }\end{array}$ & $\begin{array}{l}\text { Frequency of } \\
\text { rifampicin- } \\
\text { resistant } \\
\text { transformants }\end{array}$ & Ratio & $\begin{array}{l}\text { Frequency of } \\
\text { erythromycin- } \\
\text { resistant } \\
\text { transformants }\end{array}$ \\
\hline $\begin{array}{l}\text { TGY } \\
\text { TY } \\
\text { TY } \\
\text { TY }\end{array}$ & $\begin{array}{r}- \\
- \\
\text { TY } \\
\text { TY }\end{array}$ & $\begin{array}{l}- \\
- \\
-\end{array}$ & $\begin{array}{l}6.1 \times 10^{-4} \\
9.2 \times 10^{-4} \\
5.9 \times 10^{-4} \\
1.4 \times 10^{-2}\end{array}$ & $\begin{array}{l}1 \cdot 0 \\
1 \cdot 5 \\
1 \cdot 0 \\
23\end{array}$ & $\begin{array}{l}4 \cdot 2 \times 10^{-4} \\
7 \cdot 0 \times 10^{-4} \\
5 \cdot 2 \times 10^{-4} \\
5 \cdot 7 \times 10^{-3}\end{array}$ \\
\hline $\begin{array}{l}\text { TGY } \\
\text { TY } \\
\text { TY } \\
\text { TGY } \\
\text { TGY }\end{array}$ & $\begin{array}{l}\text { TGY } \\
\text { TY } \\
\text { TGY } \\
\text { TY }\end{array}$ & $\begin{array}{l}- \\
+ \\
+ \\
+ \\
+\end{array}$ & $\begin{array}{l}1.4 \times 10^{-4} \\
5.9 \times 10^{-3} \\
2.4 \times 10^{-3} \\
5.0 \times 10^{-3} \\
1.8 \times 10^{-3}\end{array}$ & $\begin{array}{l}1 \cdot 0 \\
42 \\
17 \\
36 \\
13\end{array}$ & $\begin{array}{l}6.4 \times 10^{-5} \\
2.6 \times 10^{-3} \\
1.2 \times 10^{-3} \\
2.0 \times 10^{-3} \\
5.5 \times 10^{-4}\end{array}$ \\
\hline
\end{tabular}


Table 2. Effect of $\mathrm{CaCl}_{2}$ concentration on the frequency of transformation of $M$. radiodurans to rifampicin-resistance

\begin{tabular}{ccc}
$\mathrm{CaCl}_{2}$ concn \\
in culture (M) & \multicolumn{2}{c}{ Transformation frequency } \\
& & Expt 1 \\
0.003 & & $1.3 \times 10^{-3}$ \\
0.01 & & $1.6 \times 10^{-3}$ \\
0.02 & & $1.4 \times 10^{-3}$ \\
0.03 & $2.1 \times 10^{-2}$ & $8.0 \times 10^{-3}$ \\
0.09 & $1.6 \times 10^{-2}$ & $8.0 \times 10^{-3}$ \\
0.17 & $2.3 \times 10^{-2}$ & \\
0.28 & $2.4 \times 10^{-2}$ & $2.2 \times 10^{-3}$ \\
0.57 & $1.4 \times 10^{-2}$ & \\
0.86 & $6.2 \times 10^{-3}$ & \\
1.43 & $2.3 \times 10^{-3}$ & $2.7 \times 10^{-3}$
\end{tabular}

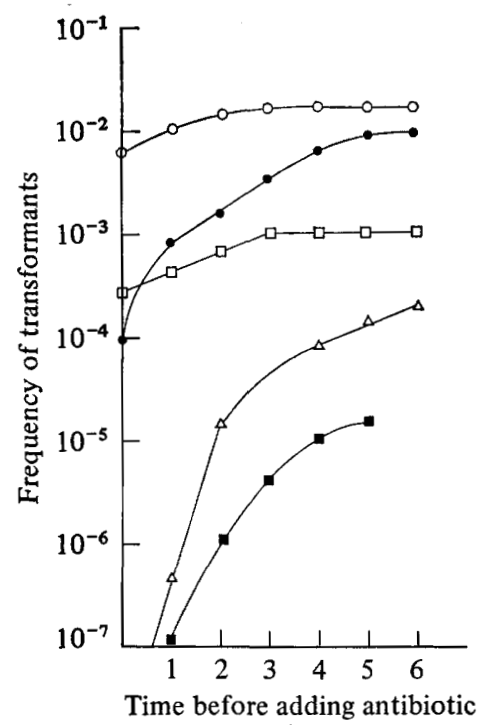

(h)

Fig. 1. Transformation frequencies in $M$. radiodurans for five resistance markers as a function of the time of addition of the inhibitory agar overlay following incubation at $30^{\circ} \mathrm{C}$. Resistance markers: $\bigcirc$, rifampicin; $\odot$, erythromycin; $\square$, acriflavin; $\triangle$, streptomycin; $\square$, kanamycin.

A culture of $M$. radiodurans was grown in TGY medium, resuspended in the same medium and different concentrations of $\mathrm{CaCl}_{2}$ were added to samples of the culture before they were exposed to transforming DNA. The frequencies of transformation obtained at the various concentrations are shown in Table 2. Maximum transformation frequencies were obtained between 0.03 and $0.28 \mathrm{M}-\mathrm{CaCl}_{2}$. Routinely we now use $0.03 \mathrm{M}$.

The ability of the divalent cations $\mathrm{Mg}^{2+}, \mathrm{Sr}^{2+}$ and $\mathrm{Zn}^{2+}$ to replace $\mathrm{Ca}^{2+}$ was tested by using $\mathrm{MgCl}_{2}, \mathrm{SrCl}_{2}$ and $\mathrm{ZnCl}_{2}$ at $0.03 \mathrm{M}$. Neither $\mathrm{Mg}^{2+}$ nor $\mathrm{Sr}^{2+}$ increased the transformation frequency while $\mathrm{Zn}^{2+}$ completely inhibited transformation.

Time required for maximum expression of transformed markers

The frequency of transformants resistant to each antibiotic as a function of the time of addition of the inhibitory overlay is shown in Fig. 1. The frequency of transformants 


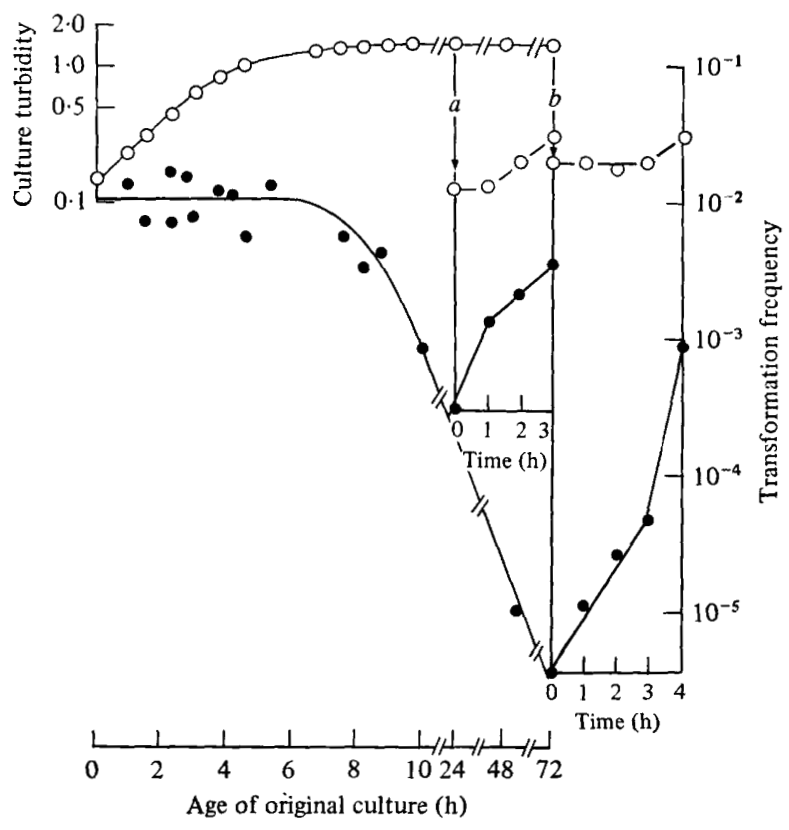

Fig. 2. Frequency of rifampicin-resistant transformants of $M$. radiodurans $(O)$ as a function of culture age. At 24 and $72 \mathrm{~h}$, samples of the original culture at a turbidity $(O)$ of 1.4 were diluted into fresh medium to give turbidities of $0.13(a)$ and $0.20(b)$ and transformation frequencies and turbidities were measured in the original and diluted cultures.

resistant to rifampicin and acriflavin was already relatively high when the inhibitory layer was added immediately after exposure to DNA. The maximum frequency was obtained after 2 to $3 \mathrm{~h}$ incubation and was about three times that at time zero. The frequencies of transformants resistant to erythromycin, streptomycin and kanamycin were relatively low at time zero and increased at least 100 -fold during post-transformation incubation, maximum frequencies being obtained only after at least $6 \mathrm{~h}$. These results made rifampicin- and acriflavin-resistance useful markers because of the relatively short expression time required.

DNA from the strain of $M$. radiodurans resistant to kanamycin, rifampicin, acriflavin, streptomycin and erythromycin was used to transform a wild-type culture and each of the markers was selected by adding the appropriate antibiotic at the time giving maximum expression for each marker. The ratio of frequencies (averaged from a large number of experiments) was: kanamycin-resistance, 1 ; streptomycin-resistance, 1 ; acriflavin-resistance 4; erythromycin-resistance, 25 ; rifampicin-resistance, 64 . Rifampicin-resistance was thus the most useful marker because of its high frequency and short expression time and it was used to examine some features of transformation in $M$. radiodurans.

\section{Transformation frequency as a function of the growth phase}

While growth of a culture of $M$. radiodurans continued through the exponential phase and into the stationary phase, samples were removed, treated as described in Methods and assayed for transformants (Fig. 2). A transformation frequency of approximately $1 \%$ was obtained when the culture was in the exponential phase of growth. The frequency of transformants decreased during the stationary phase and had fallen 5000 -fold after $72 \mathrm{~h}$. After 24 and $72 \mathrm{~h}$, samples of the stationary phase cultures were diluted into fresh TGY medium to give turbidities of 0.13 and $0 \cdot 20$, respectively, and the increase in turbidity and transformation frequency was measured. The latter began to increase during the first hour during which time there was no increase in turbidity. 


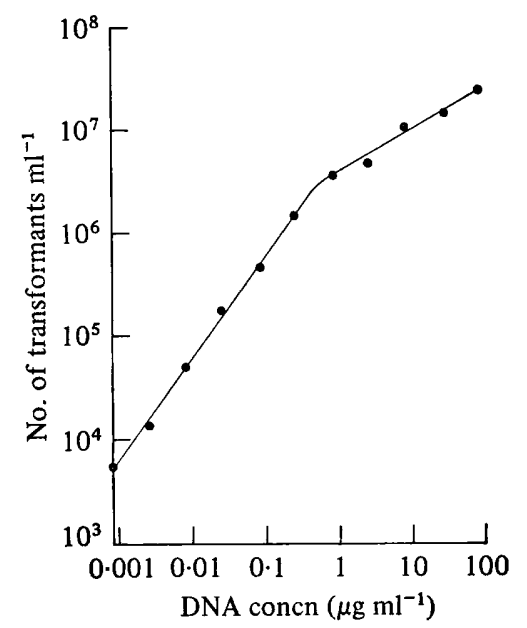

Fig. 3

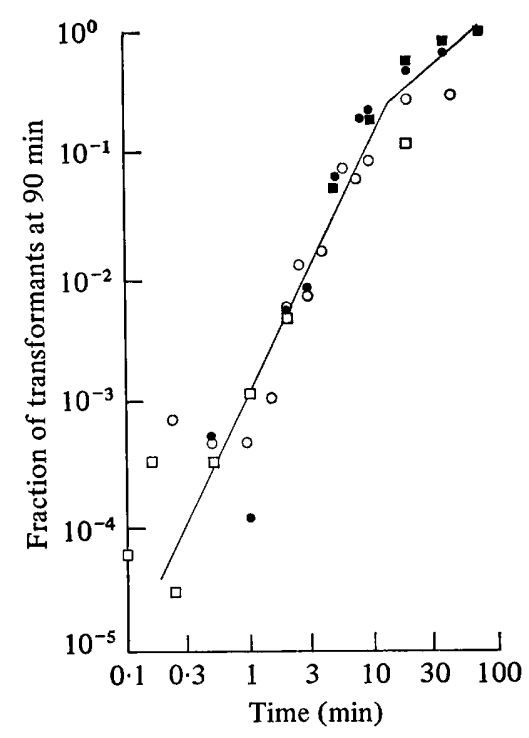

Fig. 4

Fig. 3. Number of rifampicin-resistant transformants of $M$. radiodurans as a function of transforming DNA concentration. The viable count of bacteria exposed to DNA was $6.4 \times 10^{8} \mathrm{ml}^{-1}$, the transformation frequency at the maximum concentration of DNA tested $\left(88 \mu \mathrm{g} \mathrm{ml}^{-1}\right)$ being $3.6 \times 10^{-2}$.

Fig. 4. Number of transformants of $M$. radiodurans as a function of the time of exposure to DNA. Since the results are from different experiments with different concentrations of DNA the number of transformants is plotted as a fraction of those obtained at $90 \mathrm{~min}$, the maximum incubation time tested. : DNA concentration $88 \mu \mathrm{g} \mathrm{ml}^{-1}$; number of rifampicin-resistant transformants at $90 \min 3.9 \times 10^{6} \equiv$ transformation frequency of $6.5 \times 10^{-3}$. $\bigcirc:$ DNA concentration $8.8 \mu \mathrm{g} \mathrm{ml}^{-1}$; number of rifampicin-resistant transformants at $90 \mathrm{~min} 4.0 \times 10^{6} \equiv$ frequency of $6.5 \times 10^{-3}$. $\square$ : DNA concentration $8.8 \mu \mathrm{g} \mathrm{ml}^{-1}$; number of rifampicin-resistant transformants at $90 \mathrm{~min}$ $4 \cdot 7 \times 10^{6} \equiv$ frequency of $7.8 \times 10^{-3}$. resistant transformants at $90 \mathrm{~min} 1 \cdot 1 \times 10^{4} \equiv$ frequency of $5 \cdot 0 \times 10^{-5}$.

Table 3. Frequency of rifampicin-resistant transformants in a culture of $M$. radiodurans exposed to transforming DNA $\left(8.8 \mu \mathrm{g} \mathrm{ml}^{-1}\right)$ for different periods of time

\begin{tabular}{ccr}
$\begin{array}{c}\text { Time of } \\
\text { incubation } \\
\text { with DNA }\end{array}$ & \multicolumn{2}{c}{ Rifampicin-resistant clones } \\
\cline { 2 - 3 } No. ml & N & Frequency \\
$3 \mathrm{~s}$ & $2.0 \times 10^{1}$ & $3.2 \times 10^{-8}$ \\
$6 \mathrm{~s}$ & $2.0 \times 10^{1}$ & $3.2 \times 10^{-8}$ \\
$10 \mathrm{~s}$ & $3.3 \times 10^{2}$ & $5.0 \times 10^{-7}$ \\
$30 \mathrm{~s}$ & $1.6 \times 10^{3}$ & $2.5 \times 10^{-6}$ \\
$1 \mathrm{~min}$ & $1.6 \times 10^{3}$ & $2.5 \times 10^{-6}$ \\
$2 \mathrm{~min}$ & $5.4 \times 10^{3}$ & $8.7 \times 10^{-6}$ \\
$20 \mathrm{~min}$ & $2.3 \times 10^{4}$ & $3.7 \times 10^{-5}$ \\
$90 \mathrm{~min}$ & $5.6 \times 10^{5}$ & $9.0 \times 10^{-4}$ \\
& $4.7 \times 10^{6}$ & $7.6 \times 10^{-3}$
\end{tabular}

\section{DNA saturation curve}

Samples from a culture of $M$. radiodurans prepared for transformation $\left(6.4 \times 10^{8}\right.$ viable units $\mathrm{ml}^{-1}$ ) were exposed to different concentrations of transforming DNA, and the number of rifampicin-resistant transformants was determined at each DNA concentration (Fig. 3). There was a linear increase in the number of transformants as a function of DNA concentration until the latter reached $1 \mu \mathrm{g} \mathrm{ml}^{-1}$. In excess of this concentration the linear relationship failed and for a further 100 -fold increase in concentration there was a $5 \cdot 3$-fold increase 
Table 4. Application of the unlinked marker technique to transformation of $M$. radiodurans in an attempt to measure the competent fraction of the population

Antibiotic-resistance
markers* and antibiotic
concn $\left(\mu \mathrm{g} \mathrm{m}^{-1}\right)$ used to
select transformants $\overbrace{\text { 1st marker }}^{\text {2nd marker }}$

Expt 1

\begin{tabular}{|c|c|}
\hline Rif 2 & Ery \\
\hline Rif 2 & Ery \\
\hline Rif 2 & Ery \\
\hline Rif 10 & Ery \\
\hline Rif 10 & Ery \\
\hline Rif 10 & Ery \\
\hline Rif 50 & Ery \\
\hline Rif 50 & Ery \\
\hline Rif 50 & Ery \\
\hline
\end{tabular}

Expt 2

Rif 2 Ery 5

Ery 5 Acr 1

Rif 2

Expt 3

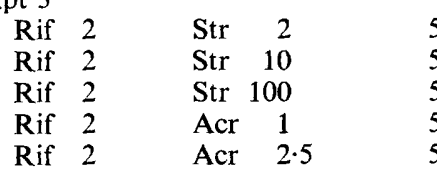

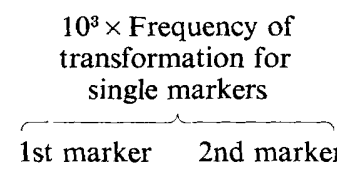

(a)

19
19
19
17
17
17
15
15
15

\section{8}

12

28

55

55

55

55

(b)

$4 \cdot 6$
$3 \cdot 5$
$2 \cdot 6$
$4 \cdot 6$
$3 \cdot 5$
$2 \cdot 6$
$4 \cdot 6$
$3 \cdot 5$
$2 \cdot 6$

12

$7 \cdot 4$

$7 \cdot 4$

0.87

0.71

$0 \cdot 57$

13

$1 \cdot 9$

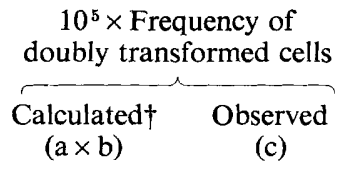

Competent fraction of population $[(\mathrm{a} \times \mathrm{b}) / \mathrm{c}]$

* Rif, Rifampicin; Ery, erythromycin; Acr, acriflavin; Str, streptomycin.

$\dagger$ Assuming the cultures to be $100 \%$ competent.

in the number of transformants. Even at $88 \mu \mathrm{g} \mathrm{DNA} \mathrm{ml}^{-1}$ there was no evidence for saturation.

\section{Kinetics of DNA uptake}

The frequency of transformation as a function of time of incubation with DNA was determined as described in Methods. When the DNA concentration was $8.8 \mu \mathrm{g} \mathrm{ml}^{-1}$ in the assay tubes the first transformants appeared after the bacteria had been exposed to DNA for between 3 and $6 \mathrm{~s}$ (Table 3). The number of transformants at $6 \mathrm{~s}$ was 16 times greater than the number of spontaneous mutants. The results from several experiments, using different concentrations of DNA and different markers, are shown in Fig. 4. It might be expected that the number of transformants would be linearly related to the time of exposure to DNA but this was not the case over the first $10 \mathrm{~min}$ when for a 10-fold increase in exposure time, e.g. 1 to $10 \mathrm{~min}$, the number of transformants increased 100 -fold, i.e. from $1.3 \times 10^{-3}$ to $1.3 \times 10^{-1}$ of the final number at $90 \mathrm{~min}$. Only from about 10 to $90 \mathrm{~min}$ did the number of transformants increase in direct proportion to the exposure time. The addition of chloramphenicol $\left(100 \mu \mathrm{g} \mathrm{ml}^{-1}\right)$ to cultures prepared for transformation $15 \mathrm{~min}$ before adding to transforming DNA did not significantly reduce the transformation frequency.

\section{Attempted measurement of competence}

Attempts were made to measure the competent fraction of the population using the unlinked marker technique (Goodgal \& Herriot, 1961; Nester \& Stocker, 1963). This method is based on the idea that in a population in which every cell is competent the frequency of cells transformed for two unlinked markers should be equal to the product of the transformation frequencies of each of the two markers individually. In a culture in which the 
competent cells form only a fraction of the population the number of doubly transformed cells will be greater than the product of the individual frequencies so that the ratio of expected to observed frequencies of doubly transformed cells should be equal to the fraction of competent cells.

Table 4 gives values for the observed transformation frequencies for different individual markers selected at various concentrations of inhibitor, for the calculated transformation frequencies for doubly transformed cells expected, assuming the whole population to be competent, for the actual frequencies of double transformants and for the fraction of the population calculated to be competent. In all cases the final values exceeded one, i.e. more than $100 \%$ of the cells in the culture were calculated to be competent, the values being from 4.0 to $22 \cdot 9$ (400 to $2290 \%$ ).

\section{DISCUSSION}

The transformation frequency in $M$. radiodurans is considerably enhanced by the presence

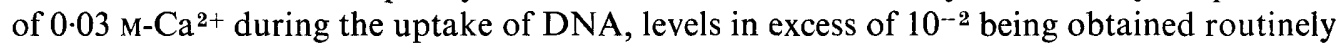
for the rifampicin-resistance marker. $\mathrm{Ca}^{2+}$ has a similar effect on other bacteria such as Escherichia coli, Diplococcus pneumoniae and Staphylococcus aureus (Mandel \& Higa, 1970; Fox \& Hotchkiss, 1957; Thompson \& Pattee, 1977) but the biochemical mechanism remains obscure. The transformation frequencies now obtained compare favourably with those in the classical transformable species Bacillus subtilis (Anagnostopoulos \& Spizizen, 1961), Diplococcus pneumoniae (Hotchkiss, 1954) and Haemophilus influenzae (Spencer \& Herriot, 1965).

An unusual feature of transformation in $M$. radiodurans is that competence does not occur as a transitory state during the growth of a culture as it does, for example, in the three species mentioned above. A culture of $M$. radiodurans is competent at all stages of exponential growth and in this resembles Neisseria meningitidis (Catlin, 1960). This relative stability of the transformation frequency during exponential growth means that it can be used, for example, to measure changes in recombinational ability (Moseley et al., 1972a).

The minimum time required for uptake of DNA into a DNAase-insensitive state of between 3 and $6 \mathrm{~s}$ is similar to that found in $H$. influenzae by Stuy \& Stern (1964). They calculated that 4 to $5 \mathrm{~s}$ is required for the penetration of $8 \times 10^{6}$ to $9 \times 10^{6}$ daltons of a DNA molecule. In $B$. subtilis the minimum time required is 1 to $1.5 \mathrm{~min}$ (Levine \& Strauss, 1965). The reasons for these variations are not known.

A second unusual feature of the $M$. radiodurans transformation system is that although the number of transformants is linearly related to the exposure time between 10 and $90 \mathrm{~min}$ this relationship does not hold during the incubation period up to $10 \mathrm{~min}$. During this period the number of transformants produced per unit time increases as though the process were becoming more efficient with time. This can best be explained in terms of at least one of the processes involved in transformation being inducible. In B. subtilis genetic transformation can be stimulated by prior exposure of the bacteria to homologous DNA or polyphosphate and Kohiyama \& Saito (1960) suggested that induction of a DNA permeating system was required. However, they could not reconcile this with the general concept of inducible enzymes since compounds which inhibited the formation of amylase, e.g. 2,4dinitrophenol, did not influence the increased rate of formation of transformants. Levine $\&$ Strauss (1965) showed that although during 1.5 to $4 \mathrm{~min}$ incubation with DNA there was a gradually increasing rate of appearance of transformants, chloramphenicol did not inhibit transformation. This result also argues against an inducible protein being synthesized as a result of exposure of $\boldsymbol{B}$. subtilis to transforming DNA. Our results support such a conclusion for $M$. radiodurans also.

The DNA saturation curve (Fig. 3) is unusual in that, in spite of very high concentrations of DNA, the number of transformants did not become constant but continued to rise with 
increasing DNA concentrations above $1 \mu \mathrm{g} \mathrm{ml}^{-1}$, albeit at a slower rate. The molecules of DNA containing the rifampicin marker were obviously becoming less efficient at transforming as a result of competition with other DNA molecules but the recipient cells appear not to have been saturated with DNA even at concentrations up to $88 \mu \mathrm{g} \mathrm{ml}^{-1}$.

Attempts to measure the competent fraction of populations of $M$. radiodurans prepared for transformation, using the unlinked marker technique, led to values greatly in excess of one. Values greater than one have been obtained previously, e.g. 1.45 was obtained by Hadden \& Nestor (1968) in B. subtilis. Porter \& Guild (1969) explained a similar result in Diplococcus pneumoniae by assuming that because transformation involves the integration of transforming DNA into only one of the two strands of a DNA helix then the two unlinked markers could either be integrated into the same or opposite strands of the helix. Although in the latter case the cell would be doubly transformed, replication of the DNA and its subsequent segregation into different daughter cells would mean that a doubly transformed cell on dividing would score as two singly transformed cells. Thus, there would be less doubly transformed cells than the calculated frequency from data from singly transformed cells would predict. If all the cells in a population were competent, a value of 2.0 would indicate that there were two transformable units per cell (assuming that there is an equal chance of transforming DNA being integrated into the same or alternate strands of the DNA helix).

The results for $M$. radiodurans with average values from each experiment (Table 4) of $5 \cdot 0,11.3$ and 14.5 cannot be assumed to be the number of transformable units since the competent fraction of the population is not known. The highest value (14.5) must be equal to, or less than, the real value. Of course, as the competent fraction of cells rises to one, the value for transformable units must approach its real value. Certainly in the three experiments described, as the competent fraction rises, indicated by the increasing frequency of rifampicin-resistant transformants $\left(1.9 \times 10^{-2}, 2 \cdot 8 \times 10^{-2}\right.$ and $\left.5.5 \times 10^{-2}\right)$, the value for transformable units rises. Recently, the genome complexity of $M$. radiodurans was calculated from DNA renaturation data, and from measurements of DNA per cell it was estimated that resting phase cells have four genome equivalents per cell while cells growing exponentially with a doubling time of $80 \mathrm{~min}$ have ten genome equivalents (Hansen, 1978). This would mean that the latter would contain 20 transformable units (single strands of DNA) and this is borne out by our results. Assuming an average of 20 transformable units per cell then the competent fraction would be the values in the final column of Table 4, viz. the calculated number of transformable units per cell assuming a competent fraction of 1.0 , divided by 20 (the real value), giving values of $0.25,0.57$ and 0.72 . From this it can be calculated that if all the cells were competent the maximum value for transformation using a single marker would be about $7 \cdot 6 \%$ for rifampicin-resistance.

The data of Hansen (1978) did not distinguish between a single chromosome containing four genome equivalents, two chromosomes of two genome equivalents, or four independent chromosomes per resting cell. Our results strongly suggest that the genome copies must be independent and capable of independent segregation. Very recent studies of the amount of DNA (estimated chemically) per nucleus (as revealed by Giemsa staining) indicate that all four genomes are contained within a single nucleus (D. M. Evans \& B. E. B. Moseley, unpublished observations). It seems likely, therefore, that recombination repair is possible between homologous regions of chromosomes while they are in this conformation, accounting for the extraordinary resistance of this bacterium to radiation damage, for example, although the four chromosomes eventually segregate as independent units.

We thank Mr H. J. R. Copland for his precision in carrying out many of the experiments described. This work was supported by a grant from the Medical Research Council to B.E. B. M. and by a Scholarship from the Iranian Ministry of Education to S. T. 


\section{REFERENCES}

Anagnostopoulos, C. \& Spizizen, J. (1961). Requirements for transformation in Bacillus subtilis. Journal of Bacteriology 81, 741-746.

Anderson, A. W., Nordan, H. C., Cain, R. F., Parrish, G. \& DugGan, D. (1956). Studies on a radioresistant micrococcus. I. Isolation, morphology, cultural characteristics and resistance to gamma radiation. Food Technology 10, 575-577.

Catlin, B. W. (1960). Transformation of Neisseria meningitidis by deoxyribonucleates from cells and from culture slime. Journal of Bacteriology 79, 579-590.

Duggan, D. E., Anderson, A. W., Elliker, P. K. \& CAIN, R. F. (1959). Ultraviolet exposure studies on a gamma radiation resistant micrococcus isolated from food. Food Research 24, 376-382.

Fox, M. S. \& HoтchкISs, R. D. (1957). Initiation of bacterial transformation. Nature, London 179, 1322-1325.

Goodgal, S. H. \& Herriot, R. M. (1961). Studies on transformations of Haemophilus influenzae. I. Competence. Journal of General Physiology 44, 1201-1227.

Hadden, C. \& Nestor, E. W. (1968). Purification of competent cells in the Bacillus subtilis transformation system. Journal of Bacteriology 95, 876-885.

Hansen, M. T. (1978). Multiplicity of genome equivalents in the radiation-resistant bacterium Micrococcus radiodurans. Journal of Bacteriology 134, 71-75.

Hotchkiss, R. D. (1954). Cyclical behaviour in pneumococcal growth and transformability occasioned by environmental changes. Proceedings of the National Academy of Sciences of the United States of America 40, 49-55.

Kerszman, G. (1975). Induction of mutation to streptomycin resistance in Micrococcus radiodurans. Mutation Research 28, 9-14.

Kohiyama, M. \& Saito, H. (1960). Stimulation of genetic transformation in Bacillus subtilis by biologically inactive DNA and polyphosphate. Biochimica et biophysica acta 41, 180-181.

Levine, J. S. \& Strauss, N. (1965). Lag period characterizing the entry of transforming deoxyribonucleic acid into Bacillus subtilis. Journal of Bacteriology 89, 281-287.

Mandel, M. \& Higa, A. (1970). Calcium-dependent bacteriophage DNA-infection. Journal of Molecular Biology 53, 159-162.

Marmur, J. (1961). A procedure for the isolation of deoxyribonucleic acid from micro-organisms. Journal of Molecular Biology 3, 208-218.

Moseley, B. E. B. (1967). The isolation and some properties of radiation-sensitive mutants of
Micrococcus radiodurans. Journal of General Microbiology 49, 293-300.

Moseley, B. E. B. \& Copland, H. J. R. (1975). Isolation and some properties of a recombination deficient mutant of Micrococcus radiodurans. Journal of Bacteriology 121, 422-428.

Moseley, B. E. B. \& Copland, H. J. R. (1978). Four mutants of Micrococcus radiodurans defective in the ability to repair DNA damaged by mitomycin $\mathrm{C}$, two of which have wild type resistance to ultraviolet light. Molecular and General Genetics 160, 331-337.

Moseley, B. E. B. \& Setlow, J. K. (1968). Transformation in Micrococcus radiodurans and the ultraviolet sensitivity of its transforming DNA. Proceedings of the National Academy of Sciences of the United States of America 61, 176-183.

Moseley, B. E. B., Mattingly, A. \& Copland, H. J. R. (1972a). Sensitization to radiation by loss of recombination ability in a temperaturesensitive DNA mutant of Micrococcus radiodurans held at its restrictive temperature. Journal of General Microbiology 72, 329-338.

Moseley, B. E. B., Mattingly, A. \& Shimmin, M. $(1972 b)$. Isolation and some properties of temperature-sensitive mutants of Micrococcus radiodurans defective in DNA synthesis. Journal of General Microbiology 70, 399-409.

Nester, E. W. \& Stocker, B. A. D. (1963). Biosynthetic latency in early stages of deoxyribonucleic acid transformation in Bacillus subtilis. Journal of Bacteriology 86, 785-796.

PorTer, R. D. \& GuILD, W. R. (1969). Number of transformable units per cell in Diplococcus pneumoniae. Journal of Bacteriology 97, 1033-1035.

SPENCER, H. T. \& Herriot, R. M. (1965). Development of competence of Haemophilus influenzae. Journal of Bacteriology 90, 911-920.

StuY, J. H. \& STERN, D. (1964). The kinetics of DNA uptake by Haemophilus influenzae. Journal of General Microbiology 35, 391-400.

Sweet, D. M. \& Moseley, B. E. B. (1974). Accurate repair of ultraviolet-induced damage in Micrococcus radiodurans. Mutation Research 23, 311318.

Sweet, D. M. \& Moseley, B. E. B. (1976). The resistance of Micrococcus radiodurans to killing and mutation by agents which damage DNA. Mutation Research 34, 175-186.

Thompson, N. E. \& Pattee, P. A. (1977). Transformation in Staphylococcus aureus; role of bacteriophage and incidence of competence among strains. Journal of Bacteriology 129, 778-788. 